Research Article, Issue 1
Analytical Methods in Environmental Chemistry Journal
Journal home page: www.amecj.com/ir

\title{
Speciation of arsenic in wastewater samples based on pyributicarbamate/ionic liquids by dispersive liquid-liquid microextraction
}

\author{
Nafiseh Esmaeilia, Nadia Kokabia , and Eskandar Kolvaria, \\ ${ }^{a}$ Department of chemistry, Faculty of Science, Semnan University, Semnan, Iran
}

A R T I C L E I N F O:

Received 6 Dec 2019

Revised form 30 Jan 2020

Accepted 15 Feb 2020

Available online 28 Mar 2020

Keywords:

Arsenic, Speciation,

Wastewater,

Pyributicarbamate,

Task specific Ionic liquid,

Dispersive liquid-liquid

microextraction

\begin{abstract}
A B S T R A C T
A simple and applied method based on O-3-Tert-butylphenyl N-(6-methoxy-2pyridyl)-N-methylthiocarbamate (Pyributicarbamate; TBMPMTC) was used for arsenic speciation $\left(\mathrm{As}_{\mathrm{III}}\right.$ and $\left.A s_{\mathrm{V}}\right)$ in urine and water samples by dispersive liquid-liquid microextraction (DLLME) procedure. The concentrations of arsenic in the liquid phase were determined by hydride generation atomic absorption spectrometry in the presence of flame accessory (HG-AAS). By procedure, a mixture of ionic liquid (0.1 g, [APMIM][PF6]@[HMIM] $\left.\left[\mathrm{PF}_{6}\right]\right)$, acetone $(0.2 \mathrm{~mL})$ and pyributicarbamate was injected into wastewater sample containing arsenic $\left(\mathrm{As}_{\mathrm{III}}\right.$ and $\left.\mathrm{As}_{\mathrm{V}}\right)$ ions, which were already extracted by pyributicarbamate at the optimized $\mathrm{pH}$. The task-specific ionic liquid (TSIL) of 1-3-aminopropyl)-3-methyl-imidazoliumhexafluorophosphate [APMIM] [PF6] was chemically synthesized and used for increasing of $\mathrm{As}(\mathrm{V})$ extraction in the liquid phase. As(III) was extracted based on the sulfur bond of pyributicarbamate at $\mathrm{pH}=5.3$. As $(\mathrm{V})$ can be extracted by amine group of TBMPMTC and [APMIM][PF6] at $\mathrm{pH}=3.0(\mathrm{As}(\mathrm{V})---\mathrm{NH} 2)$. The influence of parameters such as, $\mathrm{pH}$, amount of ionic liquid, and ligand was studied. Based on results, the LOD, enhancement factor (EF) and linear range (LR) were obtained $3.2 \mathrm{ngL}^{-1}, 9.85$ and $0.01-1.2 \mu \mathrm{g} \mathrm{L}^{-1}$, respectively. The procedure validated by certified reference material (CRM).
\end{abstract}

\section{Introduction}

The toxicities of heavy metals in waters cause to main problem in humans and environment and cannot be biodegraded as VOCs. The factories and chemical activity are real source of heavy metals such arsenic which can entrance to environment and caused different disease in humans such as, renal, liver and brain [1]. The most of arsenic in waters has two forms $\mathrm{As}(\mathrm{III})$ and $\mathrm{AS}(\mathrm{V})$. The arsenic concentration in waters has generally ranged between 1 and $2 \mu \mathrm{g} \mathrm{L}^{-1}$. Water in volcanic

\footnotetext{
* Corresponding author: Bahareh Fahimirad

Email: kolvari@semnan.ac.ir

https://doi.org/10.24200/amecj.v3.i01.93
}

rock and sulfide mineral has high levels about 12 $\mathrm{mg} \mathrm{L}^{-1}$. Mean arsenic concentrations in sediment the mean of As has ranges from 5 to $3000 \mathrm{mg} \mathrm{kg}^{-1}$ $[2,3]$. The occupational exposure and oral intake (food and water) of arsenic are the most important route in humans. The mean daily intake of arsenic from drinking water to human body must be less than $10 \mu \mathrm{g}$. By increasing of arsenic concentration in waters, dangerous diseases created in human body after drink waters for many times. Many changes in CNS and peripheral nervous system (PNS) such as, tenderness and vomiting headaches occurred for arsenic exposure. Liver and renal may moved to cancer problem as different toxicity and 
oxidation state of arsenic [4-7]. Different analytical procedure used for arsenic determination of speciation/determination in water samples. A few of them only determination without speciation such as graphite furnace atomic absorption spectrometry (GF-AAS) [8], Flame atomic absorption spectrometry (F-AAS) [9], hydride generation atomic absorption spectrometry (HG-AAS) [10], capillary electrophoresis with inductively coupled plasma-mass spectrometry (CE-ICP)[11] and arsenic species can be determined with ion chromatography coupled to inductively coupled plasma mass spectrometry (IC-ICP-MS)[12]. As low concentration of arsenic species in waters (sub ppb), sample preparation must be used before instrumental analysis. Recently, solid-phase extraction (SPE) based on nanomaterials was used to improve the extraction procedure. For this purpose, many carbon structure such as, modified activated carbon [13], carbon nanotubes [14], and alumina supported on graphene oxide [15], were reported by researchers. In addition, the liquidliquid extraction technique (LLE) and dispersive liquid-liquid microextraction (DLLME) was used for extraction analyte from liquid phase based on ligand by immiscible solvents or ionic liquid which was directly immersed in water samples and dispersed by acetone [16-22]. The organic solvents such as tetrachloride carbon are toxic. Therefore, the ionic liquids (ILs) as green solvents have used as extracting solvent. ILs has many advantages as compared to organic solvents, such as favorite vapor pressure, viscosity and density. Therefore, ILs have used as benign solvent in DLLME procedure.

In this study, a new procedure based on TBMPMTC -DLLME coupled to HG-AAS for the speciation and determination of trace amount of As (III) and As (V) in wastewater samples at $\mathrm{pH}$ of 5.3 and 3.0, respectively. Flame conditions with 1.2 $\mathrm{Lmin}^{-1}$ fuel and minimum flow air have used.

\section{Experimental}

\subsection{Apparatus}

The experiments were performed using a GBC-932 atomic absorption spectrometer equipped with a hydride generation module (HG3000-AAS -AUS). A hollow cathode lamp operated at a current of 8 $\mathrm{mA}$ and a wavelength of $193.7 \mathrm{~nm}$ with a spectral band width of $1 \mathrm{~nm}$ and deuterium background corrector was applied. The deuterium-lamp background corrector, As hollow-cathode lamp, and a circulating reaction loop was used for arsenic determination.

The instrument conditions of HG-AAS have showed in Table 1. The $\mathrm{pH}$ values of the solutions have adjusted by a digital $\mathrm{pH}$ meter (Metrohm 744, Herisau, Switzerland). A Hettich centrifuge (model EBA 20, Germany) and an ultrasonic bath with heating system (Tecno-GAZ SPA, Italy) have used.

Table 1. The instrumental parameters for analysis of arsenic

\begin{tabular}{ll}
\hline Features & Value \\
\hline Precision (\%RSD, N=10) & 1.4 \\
LOD & $3.5 \mu \mathrm{g} \mathrm{L}^{-1}$ \\
Linear range, PA & $0.1-10.3 \mu \mathrm{g} \mathrm{L}^{-1}$ \\
Wavelength & $193.7 \mathrm{~nm}$ \\
Spectral band width & $1 \mathrm{~nm}$ \\
Lamp current & $8 \mathrm{~mA}$ \\
Correlation coefficient & $\mathrm{R}=0.9997$ \\
\hline
\end{tabular}

PA $=$ Peak Area, $\mathrm{PH}=$ Peak Height

\subsection{Reagents and Materials}

All the reagents were of analytical grade. Arsenic standard solutions were prepared from a stock solution of $1000 \mathrm{mg} \mathrm{L}^{-1}$ as ultra trace in $2 \%$ nitric acid from Fluka Switzerland (CAS N: 39436). Arsenic (V) oxide prepared from Sigma, Germany $\left(\mathrm{As}_{2} \mathrm{O}_{5}\right.$; CAS N: 1303-28-2). The powder of O-3-Tert-butylphenyl N-(6-methoxy-2-pyridyl)N-methylthiocarbamate (pyributicarbamate; TBMPMTC) purchased from Sigma which was prepared dailyby DW $\left(\mathrm{C}_{18} \mathrm{H}_{22} \mathrm{~N}_{2} \mathrm{O}_{2} \mathrm{~S}\right.$; CAS N: 8867867-5, Germany). 1-Hexyl-3-methylimidazolium hexafluorophosphate $\left(\mathrm{C}_{10} \mathrm{H}_{19} \mathrm{~F}_{6} \mathrm{~N}_{2} \mathrm{P}\right.$; CID 2734175 ; $\left.[\mathrm{HMIM}]\left[\mathrm{PF}_{6}\right]\right)$ was purchased from Sigma, Germany. The ionic liquid of 1-(3-aminopropyl)3-methyl-imidazoliumhexafluorophosphate [APMIM][PF6] synthesis in center of organic chemistry in Semnan University, Iran. Sodium acetate /acetic as buffer solutions for $\mathrm{pH}$ 3-6 was 
prepared from Sigma, Germany $\left(1.5 \mathrm{~mol} \mathrm{~L}^{-1}\right)$. Ultrapure water has obtained from a water system of RIPI. The plastic, vials and glasses equipments were cleaned by soaking in $\mathrm{HNO}_{3}(1 \mathrm{M})$ and were rinsed with deionized water for 10 times prior to use.

\subsection{Sampling}

Drinking and river water samples were collected paint and chemical wastewaters from Iran. These samples were immediately acidified with $0.1 \%$ of concentrated $\mathrm{HCl}$ which provided a $\mathrm{pH}$ lower than 2. The samples have then filtered in the laboratory using a pore membrane filter $(0.45 \mu \mathrm{m}$, MachereyNagel, PTFE) to remove suspended solids.

\subsection{Synthesis of [APMIM][PF6]}

As reported by $\mathrm{Hu}$ and Yeon, the procedure of synthesis of [APMIM][PF6], was done by center of organic chemistry, Semnan. For this purposed methylimidazole and bromopropylammonium bromide $\left(\mathrm{C}_{3} \mathrm{H}_{9} \mathrm{Br}_{2} \mathrm{~N}\right)$ dissolved in acetonitrile in boiling flasks with magnetic stirrer and refluxed at $90^{\circ} \mathrm{C}$. Finally, the solution of $[\mathrm{APMIM}][\mathrm{Br}]$ was obtained. After cooling, the KPF6 (10 g) added to $20 \mathrm{~mL}$ of DW) and after $24 \mathrm{~h}$, the solvents were separated and the ionic liquid was removed by extraction in methanol/chloroform. The suspension was then filtered and washed with diethyl ether (10 times) to remove impurities [23, 24].

\subsection{Procedure}

After synthesis of [APMIM][PF6], the procedure followed by $0.5 \mathrm{~mL}$ of TBMPMTC solution ( $2 \%$, $\mathrm{w} / \mathrm{w}), \quad 0.1 \mathrm{~g}$ of 1-Hexyl-3-methylimidazolium hexafluorophosphate in acetone solution $(0.2 \mathrm{~mL})$ which was mixed and injected to $10 \mathrm{~mL}$ of sample solution containing As(III)/As(V). The cloudy solution has shaken with a vortex for $5 \mathrm{~min}$ and $\mathrm{pH}$ adjusted up to 5.3 based on favorite buffer solutions. Then, the arsenic (III) was efficiently extracted (As-:SR) in [APMIM][PF6] @ [HMIM]

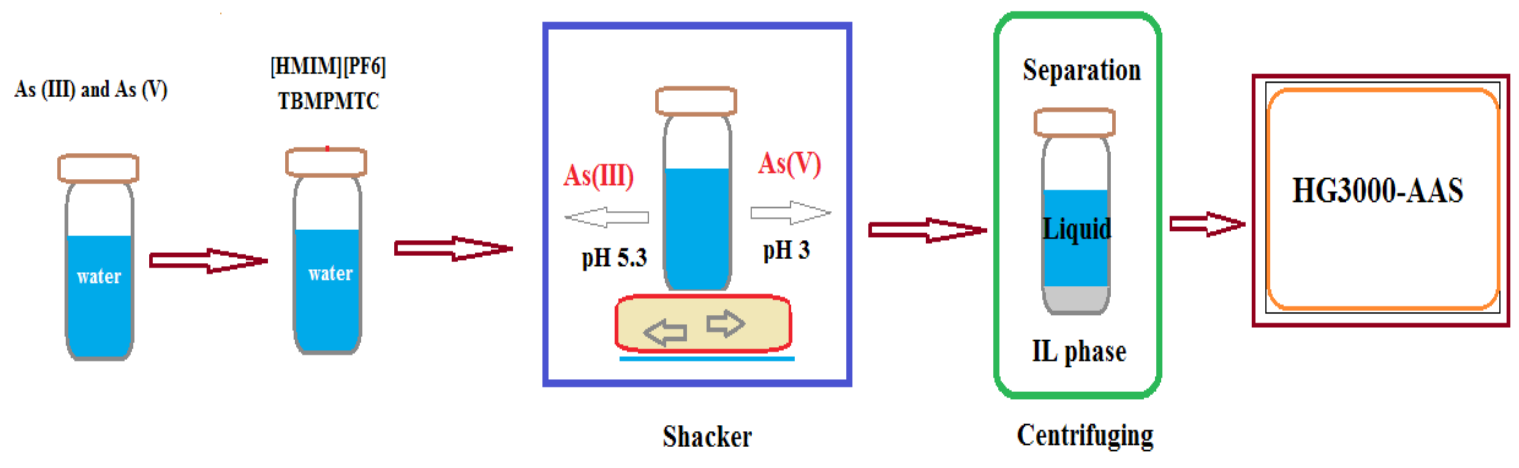

Speciation of arsenic in water samples based on pyributicarbamate by DLLME

Fig. 1. The procedure for speciation of arsenic in wastewater samples based on pyributicarbamate /ionic liquids

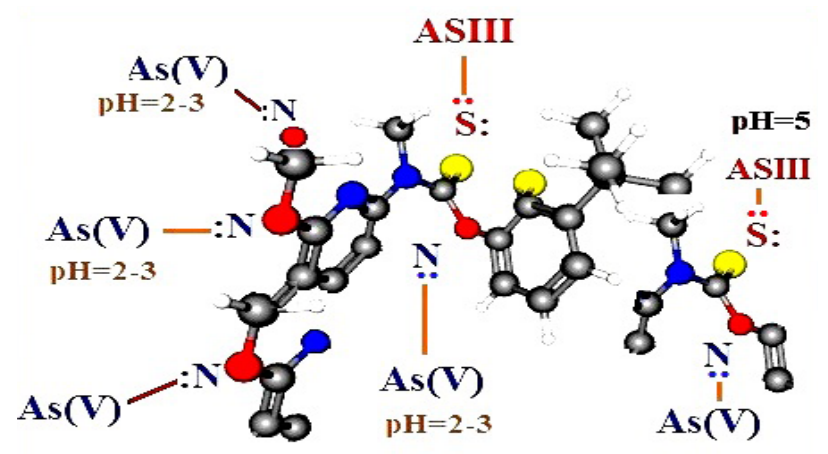

Arsenic Speciation based on Pyributicarbamate

Fig. 2. The mechanism of extraction of $\mathrm{As}(\mathrm{III})$ and $\mathrm{As}(\mathrm{V})$ based on TBMPMTC by DLLME procedure 
$\left[\mathrm{PF}_{6}\right]$. Finally, the IL separated in conical tube by centrifuging accessory for $7 \mathrm{~min}$ at $4000 \mathrm{rpm}$. The water sample removed from upper phase, arsenic (III) back extracted from IL with $0.25 \mathrm{~mL}$ of nitric acid solution $(0.5 \mathrm{M})$ in lower phase, dilution with DW up to $1 \mathrm{~mL}$ and determined by HG-AAS. $\mathrm{As}(\mathrm{V})$ was also extracted with same procedure in $\mathrm{pH}=3.0$ by mixture of TBMPMTC/[APMIM]

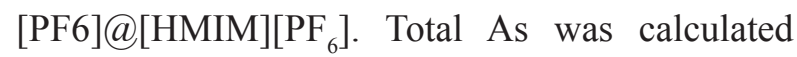
by summarizing of $\mathrm{As}(\mathrm{III})$ and $\mathrm{As}(\mathrm{V})$ which was shown in Figure 1. In addition, the mechanism of proposed procedure has presented in Figure 2.

\section{Results and Discussion}

Analytical conditions for HG-AAS determination have optimized in this work. Absorption $(\mathrm{S} / \mathrm{N})$ and repeatability that were investigated for speciation and determination $\mathrm{As}(\mathrm{III})$ and $\mathrm{As}(\mathrm{V})$ in wastewater samples in paint factories and chemical industries by HG-AAS. In view of the possibility of As extraction with TBMPMTC, this ligand was used to chelated of arsenic in ionic liquids phase. All conditions such as $\mathrm{pH}$, amount of Il, amount of TBMPMTC, sample volume and shaking time were optimized by DLLME procedure.

\subsection{Effect of $p H$}

The complexation phenomenon has strongly conditioned by the $\mathrm{pH}$ of solutions and subsequently affects on the extraction efficiency of the $\mathrm{As}_{\mathrm{III}}{ }^{-}$ $\mathrm{SR}$ and $\mathrm{As}_{\mathrm{V}}-\mathrm{SR}$. For this reason, the $\mathrm{pH}$ between 2-10 was examined for As (III) and As(V) in water samples by DLLME method. Two groups of ligands include $\mathrm{N}$ and $\mathrm{S}$ bonding have important role in speciation arsenic in liquid phase when pH optimized. Based on solubility and charge of ions, they can be extracted by bonding group of TBMPMTC. The results showed, As (III) extracted with sulfur group of TBMPMTC at $\mathrm{pH}=4.8-5.5$ and As (V) captured by amine group of TBMPMTC/ [APMIM][PF6] at $\mathrm{pH}=2.5-3.2 . \mathrm{S} 0, \mathrm{pH}$ of 3.0 and 5.0 was selected as optimum $\mathrm{pH}$ in this study (Fig.3). The $\mathrm{pH}$ adjustments of samples were made using nitric acid $\left(0.1 \mathrm{~mol} \mathrm{~L}^{-1}\right)$ for $\mathrm{pH} \mathrm{1-2,}$ and appropriate buffer solutions including sodium acetate $\left(\mathrm{CH}_{3} \mathrm{COONa} / \mathrm{CH}_{3} \mathrm{COOH}, 1-2 \mathrm{~mol} \mathrm{~L}^{-1}\right)$ for $\mathrm{pH}$ 3.75-5.75, sodium phosphate $\left(\mathrm{Na}_{2} \mathrm{HPO}_{4} /\right.$ $\mathrm{NaH}_{2} \mathrm{PO}_{4}, 0.2 \mathrm{~mol} \mathrm{~L}^{-1}$ ) for $\mathrm{pH}$ of 5.8-8.0, and ammonium chloride $\left(\mathrm{NH}_{3} / \mathrm{NH}_{4} \mathrm{Cl}, 0.2 \mathrm{~mol} \mathrm{~L}^{-1}\right)$ for pH 8-10.

\subsection{Effect of amount of TBMPMTC}

It is important to establish the favorite concentration of ligand for arsenic extraction with high recovery as shown in Figure 4. The different concentration of TBMPMTC was used for optimization of arsenic extraction from $0.5 \quad-50$ micro molar. The results showed that the 17 micro molar has

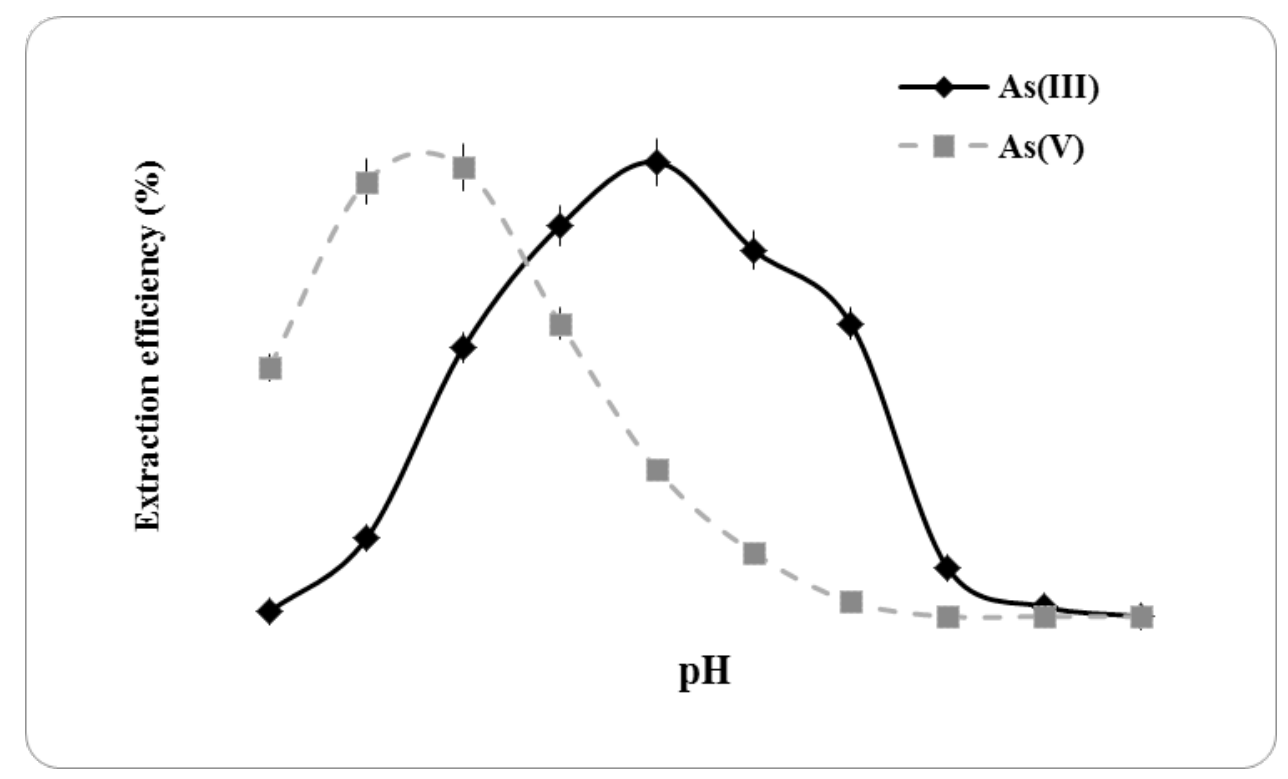

Fig. 3. The effect of $\mathrm{pH}$ on arsenic speciation based on TBMPMTC by DLLME procedure 


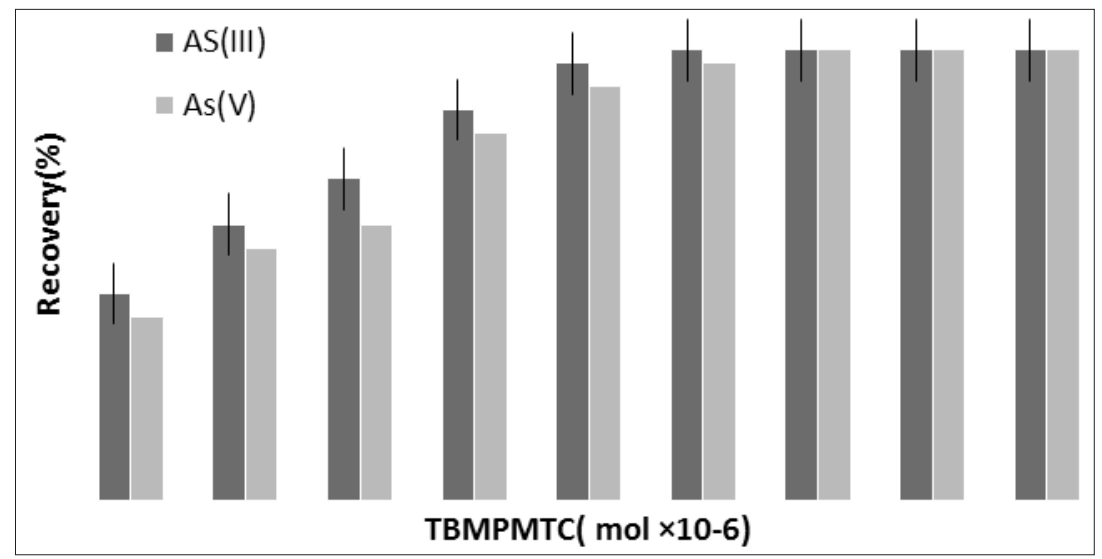

Fig. 4. The effect of amount of TBMPMTC on arsenic speciation by DLLME procedure

maximum recovery for arsenic (III, V) extraction from wastewater samples by DLLME. Based on statistical report in analytical chemistry the minimum ligand concentration was necessary to use with maximum extraction efficiency. So, the 20 micro molar selected as optimum concentration by proposed procedure.

\subsection{Effect of amount of ionic liquid}

The amount of ionic liquid as green organic solvent for extraction of arsenic in wastewaters must be optimized by DLLME. For this purpose, the different mass and kind of ionic liquid was studied. The results showed $[\mathrm{HMIM}]\left[\mathrm{PF}_{6}\right]$ have more extraction as compared to others ([BMIM] $\left.\left[\mathrm{PF}_{6}\right],[\mathrm{EMIM}]\left[\mathrm{PF}_{6}\right],[\mathrm{MMIM}]\left[\mathrm{PF}_{6}\right]\right)$. So, the 0.05$0.2 \mathrm{~g}$ of $[\mathrm{HMIM}]\left[\mathrm{PF}_{6}\right]$ examined by procedure. The quantitative extraction was observed for more than $0.08 \mathrm{~g}$ of $[\mathrm{HMIM}]\left[\mathrm{PF}_{6}\right]$ and therefore, $0.1 \mathrm{~g}$ of $[\mathrm{HMIM}]\left[\mathrm{PF}_{6}\right]$ was chosen as optimum IL for further works (Fig. 5). The [APMIM][PF6] had no effect on separation process but helped to increase efficiency extraction of $\mathrm{As}(\mathrm{V})$ from liquid phase.

\subsection{Effect of sample volume and elution}

The effect of sample volume was examined in a range of 1-20 $\mathrm{mL}$ for $\mu \mathrm{g} \mathrm{L}^{-1} \mathrm{As}(\mathrm{III})$ and $\mathrm{As}(\mathrm{V})$. The quantitative extraction has observed less than $15 \mathrm{~mL}$ wastewaters. So, $10 \mathrm{~mL}$ of sample volume was selected in optimum conditions. The acid concentrations were used in order to obtain the maximum extraction with the minimal concentration and volume of the acid solution. The presented DLLME method based on the elution of arsenic species from IL phase with a mineral acidic solution achieved. Low $\mathrm{pH}$ leads to dissociation and releasing of $\mathrm{As}$ (III) and $\mathrm{As}(\mathrm{V})$ into the aqueous phase. So, 100-500 $\mu \mathrm{L}$ of different mineral

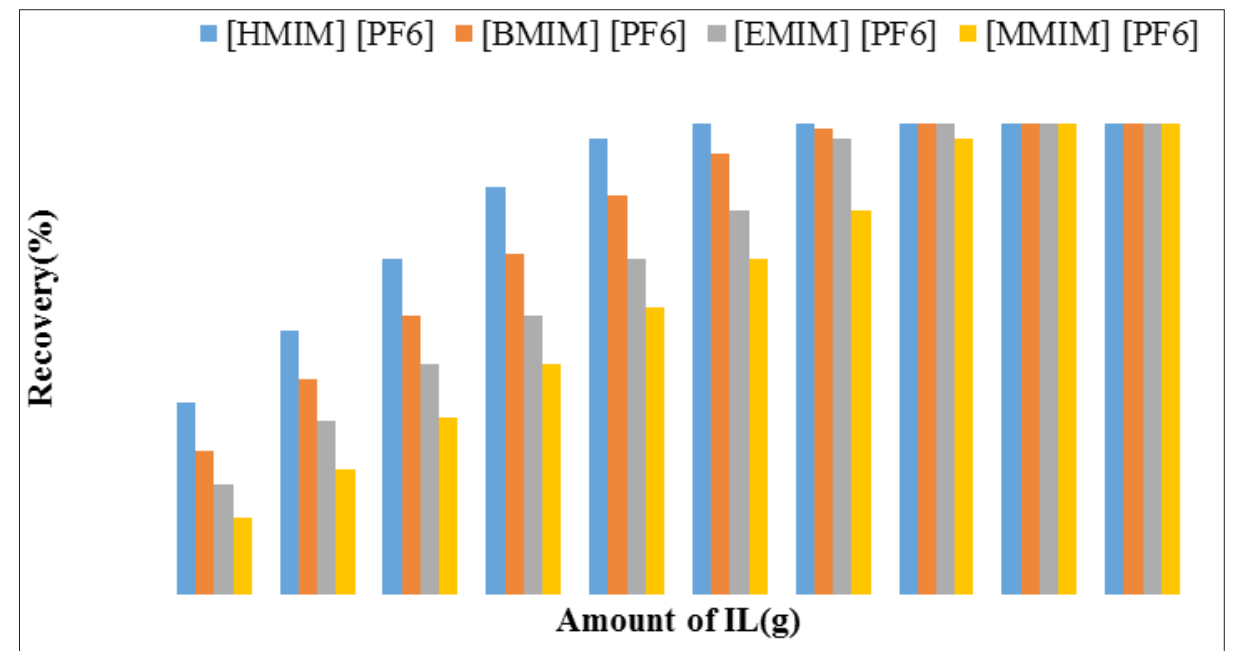

Fig. 5. The effect of amount of ionic liquid on arsenic speciation based on TBMPMTC by DLLME procedure 
acids such as $\mathrm{HCl}, \mathrm{HNO}_{3}, \mathrm{H}_{2} \mathrm{SO}_{4}$ and $\mathrm{H}_{3} \mathrm{PO}_{4}(0.1-1$ mol L-1) were examined. The results showed that $0.5 \mathrm{~mol} \mathrm{~L}^{-1} \mathrm{HNO}_{3}(250 \mu \mathrm{L})$ quantitatively backextracted arsenic from IL.

\subsection{Effect of dispersion time}

Dispersion is the main factor in arsenic extraction by DLLME method and so, allows the direct contact of the analytes with TBMPMTC ligand and then extracted. Due to the dispersion of TBMPMTC/ ILs into the aqueous phase, the mass-transference phenomenon was obtained with high efficiency in short time. The influence of the shaking time was studied within the 1-5 min. The results showed that the relative response increased at $4 \mathrm{~min}$ and then remained constant. So, 5 min was chosen as favorite time as shaking. By centrifuging, the extraction was accelerated for phase separation between IL and liquid phase. The different times for centrifuging were tested from 2 to $10 \mathrm{~min}$ at $4000 \mathrm{rpm}$. The result showed that $5 \mathrm{~min}$ centrifugation time was sufficient to get a satisfactory biphasic system.

Table 2. The effect of interferences ions on extraction of As (III) and As (V) in water samples by DLLME procedure

\begin{tabular}{|c|c|c|}
\hline $\begin{array}{c}\text { Interfering Ions } \\
\text { (M) }\end{array}$ & $\begin{array}{l}\text { Mean ratio } \\
\left(\mathrm{C}_{\mathrm{M}} / \mathrm{C}_{\mathrm{As}(\mathrm{III})}\right)\end{array}$ & $\begin{array}{c}\text { Recovery } \\
(\%)\end{array}$ \\
\hline $\mathrm{Ni}^{2+}, \mathrm{Co}^{2+}, \mathrm{Cd}^{2+}$ & 600 & 96.9 \\
\hline $\mathrm{Mn}^{2+}, \mathrm{Cu}^{2+}, \mathrm{Zn}^{2+}$ & 900 & 98.7 \\
\hline $\mathrm{I}^{-}, \mathrm{Br}^{-}, \mathrm{F}^{-}, \mathrm{Cl}^{-}$ & 1100 & 99.2 \\
\hline $\mathrm{Na}^{+}, \mathrm{K}^{+}, \mathrm{Ca}^{2+}, \mathrm{Mg}^{2+}$ & 900 & 98.2 \\
\hline $\mathrm{NO}_{3}^{-}, \mathrm{Cl}^{-}, \mathrm{F}^{-}, \mathrm{CO}_{3}^{2-}$ & 1200 & 97.4 \\
\hline $\mathrm{Hg}^{2+}$ & 100 & 95.5 \\
\hline $\mathrm{NH}_{4}^{+}, \mathrm{SO}_{4}^{2-}$ & 400 & 96.8 \\
\hline $\mathrm{Pb}^{2+}$ & 250 & 97.3 \\
\hline $\begin{array}{c}\text { Interfering Ions } \\
\text { (M) }\end{array}$ & $\begin{array}{l}\text { Mean ratio } \\
\left(\mathrm{C}_{\mathrm{M}} / \mathrm{C}_{\mathrm{As}(\mathrm{V})}\right)\end{array}$ & $\begin{array}{c}\text { Recovery } \\
(\%)\end{array}$ \\
\hline $\mathrm{Ni}^{2+}, \mathrm{Co}^{2+}, \mathrm{Cd}^{2+}$ & 500 & 96.9 \\
\hline $\mathrm{Mn}^{2+}, \mathrm{Cu}^{2+}, \mathrm{Zn}^{2+}$ & 800 & 98.7 \\
\hline $\mathrm{I}^{-}, \mathrm{Br}^{-}, \mathrm{F}^{-}, \mathrm{Cl}^{-}$ & 900 & 99.2 \\
\hline $\mathrm{Na}^{+}, \mathrm{K}^{+}, \mathrm{Ca}^{2+}, \mathrm{Mg}^{2+}$ & 900 & 98.2 \\
\hline $\mathrm{NO}_{3}^{-}, \mathrm{Cl}^{-}, \mathrm{F}^{-}, \mathrm{CO}_{3}^{2-}$ & 1200 & 97.4 \\
\hline $\mathrm{Hg}^{2+}$ & 200 & 95.5 \\
\hline $\mathrm{NH}_{4}^{+}, \mathrm{SO}_{4}^{2-}$ & 500 & 96.8 \\
\hline $\mathrm{Pb}^{2+}$ & 300 & 97.3 \\
\hline
\end{tabular}

\subsection{Interference of coexisting ions}

As efficient analytical procedure in water samples, the interference of some coexisting ions was investigated in optimized condition. By DLLME procedure, the different concentration of the interfering ions added to $10 \mathrm{~mL}$ of standard sample solution containing $1.0 \mu \mathrm{g} \mathrm{L}^{-1}$ of As (III) and As (V). The results showed that most of concomitant ions have no effect on the extraction efficiencies of As (III) and As (V) at the optimized pH. The tolerable concentration ratio of metals per As (III) and $\mathrm{As}(\mathrm{V})$ for $\mathrm{Ni}^{2+}, \mathrm{Co}^{2+}, \mathrm{Cd}^{2+}, \mathrm{Mn}^{2+}, \mathrm{Cu}^{2+}, \mathrm{Zn}^{2+}$, $\mathrm{K}^{+}, \mathrm{Na}^{+}, \mathrm{Pb}^{2+}, \mathrm{Hg}^{2+}, \mathrm{NO}_{3}{ }^{-}, \mathrm{Cl}^{-}, \mathrm{F}^{-}, \mathrm{CO}_{3}{ }^{2-}$ and $\mathrm{SO}_{4}{ }^{2-}$ was obtained in water samples (Table 2).

\subsection{Validation}

The DLLME method based on TBMPMTC as a ligand was used for determination of As (III) and As (V) in $10 \mathrm{~mL}$ of wastewater and water samples by HG-AAS. The results were verified by spiking water samples with nickel standard solution. Based on results, the acceptable recovery was achieved by adding standard solution (As (III) and As (V) to real samples as a found analyte amount. The recoveries of spiked samples were $95-103 \%$ by DLLME methods (Table 3). Wastewaters of a chemical factory (A), a paint factory (B), well water (C), and drinking water (D) were selected as real samples which were used by procedure. The results demonstrated that TBMPMTC-DLLME can used for speciation of As (III) and As (V) in wastewater, and water samples which were determined by HGAAS. In addition, the certified reference material (CRM, NIST 2670) was used for validation As (III) and As (V) in urine samples by TBMPMTCDLLME (Table 4).

\section{Conclusions}

The procedure has many advantage such as simplicity, reliability and high extraction efficiency in short time for arsenic speciation based on TBMPMTC-DLLME by sensitive HG-AAS technique. By improving the procedure, the favorite and acceptable preconcentration/separation/ speciation of the trivalent and pentavalent inorganic 
Table 3. Speciation and determination of As (III) and As (V) in spiked water samples by TBMPMTC-DLLME method

\begin{tabular}{|c|c|c|c|c|c|c|c|}
\hline \multirow[b]{2}{*}{ Sample } & \multicolumn{2}{|c|}{${ }^{\mathrm{a}}$ Added $\left(\mu \mathrm{g} \mathrm{L}^{-1}\right)$} & \multicolumn{2}{|c|}{${ }^{\mathrm{a}}$ Found $\left(\mu \mathrm{g} \mathrm{L}^{-1}\right)$} & \multirow[b]{2}{*}{ Total } & \multicolumn{2}{|c|}{ Recovery (\%) } \\
\hline & As (III) & As (V) & As (III) & $\operatorname{As}(\mathbf{V})$ & & As (III) & As (V) \\
\hline \multirow[t]{3}{*}{ A } & ------ & ------ & $0.432 \pm 0.023$ & $0.266 \pm 0.014$ & $0.698 \pm 0.037$ & ------ & ------ \\
\hline & 0.4 & ------ & $0.827 \pm 0.043$ & $0.262 \pm 0.015$ & $1.089 \pm 0.052$ & 98.8 & ------ \\
\hline & ------ & 0.3 & $0.435 \pm 0.022$ & $0.568 \pm 0.028$ & $1.003 \pm 0.049$ & ------ & 100.6 \\
\hline \multirow[t]{3}{*}{ B } & ------ & ------ & $0.501 \pm 0.023$ & $0.197 \pm 0.011$ & $0.698 \pm 0.034$ & ------ & ------ \\
\hline & 0.5 & ----- & $0.993 \pm 0.048$ & $0.195 \pm 0.009$ & $1.188 \pm 0.057$ & 98.4 & ------ \\
\hline & ----- & 0.3 & $0.498 \pm 0.024$ & $0.504 \pm 0.026$ & $1.002 \pm 0.055$ & ------ & 102.3 \\
\hline \multirow[t]{3}{*}{$\mathrm{C}$} & ------ & ------ & $0.102 \pm 0.006$ & $0.068 \pm 0.003$ & $0.170 \pm 0.009$ & ------ & ------ \\
\hline & 0.1 & ----- & $0.203 \pm 0.009$ & $0.064 \pm 0.003$ & $0.267 \pm 0.012$ & 101.0 & ------ \\
\hline & ----- & 0.1 & $0.098 \pm 0.005$ & $0.165 \pm 0.013$ & $0.263 \pm 0.018$ & ------ & 97 \\
\hline \multirow[t]{3}{*}{$\mathrm{D}$} & ------ & ------ & $0.032 \pm 0.001$ & ND & $0.032 \pm 0.001$ & ------ & ------ \\
\hline & 0.05 & ------ & $0.081 \pm 0.004$ & ND & $0.081 \pm 0.004$ & 98 & ------ \\
\hline & ------ & 0.05 & $0.030 \pm 0.001$ & $0.002 \pm 0.048$ & $0.078 \pm 0.003$ & ------ & 96 \\
\hline
\end{tabular}

${ }^{\mathrm{a}}$ Mean of three determinations \pm Confidence interval $(\mathrm{P}=0.95)$

Table 4. Method validation for speciation of arsenic based on TBMPMTC-DLLME by standard reference material $\left(\mathrm{ng} \mathrm{L}^{-1}\right)$

\begin{tabular}{lcccccc}
\hline sample & $\begin{array}{c}\text { Certified value } \\
\text { As (III) }\end{array}$ & $\begin{array}{c}\text { Certified value } \\
\text { As (V) }\end{array}$ & $\begin{array}{c}\text { *Found } \\
\text { As (III) }\end{array}$ & $\begin{array}{c}\text { *Found } \\
\text { As (V) }\end{array}$ & $\begin{array}{c}\text { Recovery } \\
\text { As (III) (\%) }\end{array}$ & $\begin{array}{c}\text { Recovery } \\
\text { As (V) (\%) }\end{array}$ \\
\hline CRM & 833.3 & 500.0 & $827.4 \pm 45.6$ & $488.7 \pm 24.6$ & 99.3 & 97.7 \\
Added & 400.0 & ------ & $1209.8 \pm 58.5$ & $482.3 \pm 26.3$ & 95.6 & ------ \\
Added & ----- & 500.0 & $831.2 \pm 51.2$ & $990.2 \pm 47.7$ & ----- & 100.3 \\
\hline
\end{tabular}

${ }^{\mathrm{a}} \mathrm{NIST}$ CRM 2670, Arsenic in frozen dried urine, $\mathrm{pH} 4.0,-20^{\circ} \mathrm{C}$, diluted with DW(1:3)

${ }^{\mathrm{b}}$ Mean of three determinations \pm confidence interval $(\mathrm{P}=0.95)$

forms of arsenic was achieved as alternative to HPLC-ICP-MS. The results showed the quantitative recovery more than $96 \%$ and $\mathrm{EF}$ of 9.85 as curve fitting analysis for $\mathrm{As}(\mathrm{III}) / \mathrm{As}(\mathrm{V})$ were obtained at $\mathrm{pH}$ of 5.0 and 3.0, respectively. If the ionic liquid of [APMIM][PF6] as TSIL wasn't used, the recovery obtained up to $73 \%$ for $\mathrm{As}(\mathrm{V})$ in optimized conditions. The certified reference material and spiking real samples showed the high accuracy and precisions results which were agreement with the certified values. In DLLME procedures, the satisfactory results based on TBMPMTC ligand was achieved for arsenic species in wastewater samples.

\section{References}

[1] R. Dixit, D. Malaviya, K. Pandiyan, U.B. Singh, A. Sahu, R. Shukla, B.P. Singh, J.P. Rai, P.K. Sharma, H. Lade, Bioremediation of heavy metals from soil and aquatic environment: an overview of principles and criteria of fundamental processes,
Sustainability, 7 (2015) 2189-2212.

[2] R. Nickson, J. McArthur, W. Burgess, K.M. Ahmed, P. Ravenscroft, M. Rahmanñ, Arsenic poisoning of Bangladesh groundwater, Nat., 395 (1998) 338338.

[3] M. Tuzen, K.O. Saygi, I. Karaman, M. Soylak, Selective speciation and determination of inorganic arsenic in water, food and biological samples, Food Chem. Toxicol., 48 (2010) 41-46.

[4] V.M. Nurchi, A.B. Djordjevic, G. Crisponi, J. Alexander, G. Bjørklund, J. Aaseth, Arsenic toxicity: Molecular targets and therapeutic agents, Biomolecul., 10 (2020) 235.

[5] M. Molin, S.M. Ulven, H.M. Meltzer, J. Alexander, Arsenic in the human food chain, biotransformation and toxicology-Review focusing on seafood arsenic, J. Trace Elem. Med. Biol., 31 (2015) 249259.

[6] A. Emadi, S.D. Gore, Arsenic trioxide - an old drug rediscovered, Blood Rev., 24 (2010) 191-199.

[7] C.M. George, L. Sima, M. Arias, J. Mihalic, L.Z. Cabrera, D. Danz, W. Checkley, R.H. 
Gilman, Arsenic exposure in drinking water: an unrecognized health threat in Peru, Bull. World Health Org., 92 (2014) 565-572.

[8] A.Q. Shah, T.G. Kazi, J.A. Baig, M.B. Arain, H.I. Afridi, G.A. Kandhro, S.K. Wadhwa, N.F. Kolachi, Determination of inorganic arsenic species (As3+ and As5+) in muscle tissues of fish species by electrothermal atomic absorption spectrometry (ETAAS), Food chem., 119 (2010) 840-844.

[9] C. Zeng, Y. Yan, J. Tang, Y. Wu, S. Zhong, Speciation of Arsenic (III) and Arsenic (V) based on Triton $\mathrm{X}-100$ hollow fiber liquid phase microextraction coupled with flame atomic absorption spectrometry, Spect. Lett., 50 (2017) 220-226.

[10] M. Welna, P. Pohl, Potential of the hydride generation technique coupled to inductively coupled plasma optical emission spectrometry for non-chromatographic As speciation, J. Anal. Atomic Spect., 32 (2017) 1766-1779.

[11] L. Liu, Z. Yun, B. He, G. Jiang, Efficient interface for online coupling of capillary electrophoresis with inductively coupled plasma-mass spectrometry and its application in simultaneous speciation analysis of arsenic and selenium, Anal. Chem., 86 (2014) 8167-8175.

[12] S.H. Son, W.B. Lee, D. Kim, Y. Lee, S.H. Nam, An alternative analytical method for determining arsenic species in rice by using ion chromatography and inductively coupled plasma-mass spectrometry, Food Chem., 270 (2019) 353-358.

[13] R. Sawana, Y. Somasundar, V.S. Iyer, B. Baruwati, Ceria modified activated carbon: an efficient arsenic removal adsorbent for drinking water purification, Appl. Water Sci., 7 (2017) 1223-1230.

[14] A. Naghizadeh, A.R. Yari, H.R. Tashauoei, M. Mahdavi, E. Derakhshani, R. Rahimi, P. Bahmani, H. Daraei, E. Ghahremani, Carbon nanotubes technology for removal of arsenic from water, Arch. Hyg. Sci., 1 (2012) 6-11.

[15] A. Baranik, A. Gagor, I. Queralt, E. Marguí, R. Sitko, B. Zawisza, Determination and speciation of ultratrace arsenic and chromium species using aluminium oxide supported on graphene oxide, Talanta, 185 (2018) 264-274.

[16] J. Ali, M. Tuzen, T.G. Kazi, Determination of Total Arsenic in Water and Food Samples by Pressureinduced Ionic Liquid-based Dispersive LiquidLiquid Microextraction Method Prior to Analysis by Hydride Generation Atomic Absorption Spectrometry, Atomic Spect., 38 (2017) 57-64.

[17] X. Wang, G. Xu, P. Chen, Y. Sun, X. Yao, Y. Lv, W. Guo, G. Wang, Fully-automated magnetic stirringassisted lab-in-syringe dispersive liquid-liquid microextraction for the determination of arsenic species in rice samples, RSC Adv., 8 (2018) 1685816865.

[18] E.F. Fiorentini, B.V. Canizo, R.G. Wuilloud, Determination of As in honey samples by magnetic ionic liquid-based dispersive liquidliquid microextraction and electrothermal atomic absorption spectrometry, Talanta, 198 (2019) 146153.

[19] H Shirkhanloo, M Ghazaghi, MM Eskandari, Cloud point assisted dispersive ionic liquidliquid microextraction for chromium speciation in human blood samples based on isopropyl 2-[(isopropoxycarbothiolyl) disulfanyl, Anal. Chem. Res., 10 (2016)18-27.

[20] H Shirkhanloo, A Khaligh, HZ Mousavi, MM Eskandari, AA Miran-Beigi, Ultra-trace arsenic and mercury speciation and determination in blood samples by ionic liquid-based dispersive liquid-liquid microextraction combined with flow injection, Chem. Papers, 69 (2015) 779-790.

[21] H Shirkhanloo, ZH Mousavi, A Rouhollahi, Preconcentration and determination of heavy metals in water, sediment and biological samples, J. Serb. Chem. Soc., 76 (2011) 1583-1595.

[22] H Shirkhanloo, AAM Beigi, MM Eskandari, B Kalantari, Dispersive liquid-liquid microextraction based on task-specific ionic liquids for determination and speciation of chromium in human blood, J. Anal. Chem., 70 (2015) 1448-1455

[23] Q. Hu, J. Zhao, F. Wang, F. Huo, H. Liu, Selective extraction of vanadium from chromium by pure [C8mim][PF6]: An anion exchange process, Sep. Purif. Technol., 131 (2014) 94-101.

[24] S.-H. Yeon, K.-S. Kim, S. Choi, H. Lee, H.S. Kim, H. Kim, Physical and electrochemical properties of 1-(2-hydroxyethyl)-3-methyl imidazolium and $\mathrm{N}$-(2-hydroxyethyl)-N-methyl morpholinium ionic liquids, Electrochim. Acta, 50 (2005) 5399-5407. 